\title{
Genetic Diversity and Differentiation of Colletotrichum spp. Isolates Associated with Leguminosae Using Multigene Loci, RAPD and ISSR
}

\author{
Farshid Mahmodi ${ }^{1}$, J. B. Kadir ${ }^{1 *}$, A. Puteh ${ }^{2}$, S. S. Pourdad ${ }^{3}$, A. Nasehi ${ }^{1}$ and N. Soleimani ${ }^{1}$ \\ ${ }^{I}$ Department of Plant Protection, Faculty of Agriculture, University Putra Malaysia, Serdang, 43400, Selangor, Malaysia \\ ${ }^{2}$ Department of Crop Science, Faculty of Agriculture, University Putra Malaysia, Serdang, 43400, Selangor, Malaysia \\ ${ }^{3}$ Dry-land Agricultural Research Institute (DARI), Kermanshah, Iran
}

(Received on June 8, 2013; Revised on November 29, 2013; Accepted on December 1, 2013)

Genetic diversity and differentiation of 50 Colletotrichum spp. isolates from legume crops studied through multigene loci, RAPD and ISSR analysis. DNA sequence comparisons by six genes (ITS, ACT, Tub2, CHS-1, GAPDH, and HIS3) verified species identity of $C$. truncatum, $C$. dematium and $C$. gloeosporiodes and identity $C$. capsici as a synonym of $C$. truncatum. Based on the matrix distance analysis of multigene sequences, the Colletotrichum species showed diverse degrees of intera and interspecific divergence ( 0.0 to 1.4\%) and (15.5-19.9), respectively. A multilocus molecular phylogenetic analysis clustered Colletotrichum spp. isolates into 3 well-defined clades, representing three distinct species; $C$. truncatum, $C$. dematium and $C$. gloeosporioides. The ISSR and RAPD and cluster analysis exhibited a high degree of variability among different isolates and permitted the grouping of isolates of Colletotrichum spp. into three distinct clusters. Distinct populations of Colletotrichum spp. isolates were genetically in accordance with host specificity and inconsistent with geographical origins. The large population of $\boldsymbol{C}$. truncatum showed greater amounts of genetic diversity than smaller populations of $C$. dematium and $C$. gloeosporioides species. Results of ISSR and RAPD markers were congruent, but the effective maker ratio and the number of private alleles were greater in ISSR markers.

Keywords : Colletotrichum spp., genetic diversity, ISSR, multigene loci, RAPD

Since the initial report of DNA amplification using PCR, the number of different applications of the technique has grown exponentially (Mullis et al., 1986). One of the first applications of PCR in mycology was described in 1990 by

*Corresponding author.

Phone) +603-8947-4845, FAX) +603-8938-1014

E-mail)kaju@putra.upm.edu.my
White and co-worker and dealt with the amplification and direct sequencing of ribosomal DNA (rDNA) to establish the taxonomic and phylogenic relationships among fungi (White et al., 1990). The advent of PCR has enabled the development of powerful molecular makers for the detection or discrimination of fungi, either at the species or at the strain level, and extensive applications have largely been found in mycology, including taxonomy, phylogeny, and diagnostics. PCR-based detection of pathogenic fungi has been reported for several important genuses such as Phytophtora sp., Fusarium sp. and Colletotrichum sp. (Sherriff et al., 1994; Than et al., 2008; Cai et al., 2009; Cannon et al., 2012). PCR-based techniques based on DNA sequencing have the advantage of being specific, sensitive, and rapid compared to many other detection methods (Casimiro et al., 2004). A wealth of methodologies exists for detection of microorganisms, including traditional quantification of fruiting structures, scoring of disease symptoms, biochemical and microbiological methods. Recently, polymerase chain reaction (PCR)-based methods have gained an astonishing popularity in the field of diagnostics, because of sensitivity, specificity and ease of implementation (Sachse, 2004).

Ciampi et al. (2008) stated in the rating of genetic structures of pathogen populations it is good to know about their characteristic and evolutionary processes that shaped those populations in agroecosystems. Pathogen populations with a "mixed reproduction system, high gene flow, large effective population sizes, and high mutation rates" are more likely to overcome genetic resistance from hosts than populations with opposite characteristics (McDonald and Linde, 2002). Molecular analysis using RLFP, RAPD and ISSR demonstrated that occasional transfer of specific chromosomes may occur between apparently genetically distinct isolated clonal lines of biotypes of Colletotrichum spp. producing new pathotypes on different host plant (Masel et al., 1996). In addition to sexual recombination, diversity in fungal populations can also 
arise from transposable elements and mitotic reciprocal translocation events (Kistler and Miao, 1992). Genetic diversity can result from accumulation of mutations, and these mutational processes can produce variation within a species or population (Milgroom, 1996). In many instances constraints on genetic recombination such as mycelia or vegetative incompatibility exist in asexual pathogen populations producing clonal population structures (Masele et al., 1996). Molecular assays such as RAPD, ISSR markers and other techniques have elucidated genotype variation within and among these species. Such findings have led to more complex population species evaluations and to implications that members may in fact be subdivided into strains or isolate groups, based upon these markers. RAPD markers have become useful because this polymerase chain reaction (PCR) based technique is easy to implement by amplifying random DNA segments with short oligonucleotide primers (Williams et al., 1990). Primers with more than $50 \%$ GC content are desired because six or more GC base pair can form a strong enough duplex to be extended during polymerization. Guthrie et al. (1992) showed the potential use of RAPDs for identifying and differentiating isolates of Colletotrichum $\mathrm{sp}$. that were collected from different regions of Africa, the United States, India and Puerto Rico. Results from this work indicated that some isolates have characteristic patterns based on geographic origin (Guthrie et al., 1992). RAPD also requires no sequence information, because a single short (10 base long) oligonucleotide of random sequence fulfills the same function as both primers in traditional PCR and there is a high probability of its annealing in many parts of the genome. When two primer binding sites on opposite strands fulfill certain criteria of proximity and orientation, the fragments will be multiplied exponentially. These criteria are not frequently fulfilled throughout the genome, but where the conditions are met, the DNA being amplified will tend to be the same set of fragments from related isolates (McDonald, 1997; Sherriff et al., 1995). RAPD makers have many complications that must be weighed against their relative ease of use, that make them difficult to reproduce between laboratories and sometimes within the same laboratory (McDonald, 1997). One explanation for different results from identical experiments is that RAPD pattern may be influenced by many technical factors that may be differ among laboratories (Penner et al., 1993). ISSR are hyper-variable markers based on microsatellites, but rather than genotyping microsatellite themselves, primers are designed to amplify the regions between microsatellite loci. This produces a genetic fingerprint from single primer polymerase chain reactions (Hettwer and Gerowitt, 2004;
Mort et al., 2003; Wolfe et al., 1998). Legumes are the second most important crop plants after cereals in their importance based on area harvested and total production. They have been grown in about 190 million hectares, and the world's production is approximately 300 million tons worldwide (Graham and Vance, 2003). The ability of legumes to fix atmospheric nitrogen $(\mathrm{N})$ in the soil through their symbiotic association with Rhizobium bacteria, thereby reducing the need for fertilizers, and to serve as rotation crops is very important to current agricultural production systems (Serraj, 2004). There have only been a few dispersed studies on the causal agents of anthracnose disease on legumes in Malaysia. The literature search indicated that no thorough investigations have ever been carried out on the causal agent of anthracnose on legumes in Malaysia. Therefore, studies on Colletotrichum species associated with anthracnose of legume crops in Malaysia have addressed in this research. In addition, the genetic diversity of Colletotrichum spp. populations from diverse host plants of legumes and different geographical region was investigated. The results of the present study provide better insights into the diversity and etiology of the pathogen and this will be helpful in the development of better disease management strategies and in the breeding of resistant varieties for legume production in Malaysia. The research focused on determining the genetic diversity among isolates of Colletotrichum spp. associated with grain legumes in Malaysia. Therefore, Multigene loci and molecular makers (RAPD and ISSR) were used to detect variations within and among species population.

\section{Materials and Methods}

Fungal isolates. Colletotrichum spp. isolates were obtained from symptomatic legume crops, including soybean, bean, pea, limabean, lentil, chickpea, peanut, cowpea, winged bean and country bean from various experimental and commercial farms in west of Malaysia, from the states of Selangor and Pahang (Table 1). Isolates collected from these locations, represented a range of geographic areas, host plants and species histories. Small pieces of plant tissues were taken out from the edge of healthy and infected tissues, surface sterilized in 1\% sodium hypochlorite for 2 minutes, rinsed twice with distilled water, and after drying on sterilized tissue paper, plated on PDA (Potato Dextrose Agar). Where, spore masses were formed on plant tissues, the single spore isolation technique was applied for isolation. Conidia masses from lesions on the surface of the pods were removed with a sterile needle. A reasonable spore suspension was made with spore masses and spread onto 
Table 1. Isolates of Colletotrichum spp. associated with leguminosae, with the GenBank accession numbers of six genes

\begin{tabular}{|c|c|c|c|c|c|c|c|c|c|}
\hline Ixon & $\begin{array}{l}\text { Strain } \\
\text { no. }\end{array}$ & Host & Site & $\begin{array}{c}\text { GeneBank } \\
\text { no. ITS }\end{array}$ & $\begin{array}{c}\text { GeneBank } \\
\text { no. } \beta \text {-tubulin }\end{array}$ & $\begin{array}{l}\text { GeneBank } \\
\text { no. CHS I }\end{array}$ & $\begin{array}{l}\text { GeneBank } \\
\text { no. GPDH }\end{array}$ & $\begin{array}{c}\text { GeneBank } \\
\text { no. Actin }\end{array}$ & $\begin{array}{l}\text { GeneBank } \\
\text { no. Histone }\end{array}$ \\
\hline truncatum & $\Gamma \mathrm{M} 1^{*}$ & ybean & langor & 124 & 59 & 539 & 579 & 356 & 499 \\
\hline .truncatum & TM2 & oybean & elangor & 25 & & 40 & 80 & 357 & 500 \\
\hline truncatum & TM3 & Soybean & langor & JX971126 & $\mathrm{KC}$ & 9541 & 581 & 358 & 501 \\
\hline C.truncatum & TM4 & oybean & langor & 127 & 462 & 542 & 582 & 359 & 502 \\
\hline C.truncatum & $\mathrm{CTM}^{*}$ & Bean & ahang & JX971128 & KC109463 & KC109543 & KC109583 & 5360 & 9503 \\
\hline truncatum & TM6 & Bean & & JX971129 & 464 & KC109544 & 9584 & 361 & 504 \\
\hline C.truncatum & TM7 & Bean & hang & X971130 & 465 & 9545 & 585 & 362 & 505 \\
\hline C.truncatum & TM8 & Bean & & JX971131 & KC109466 & KC109546 & 586 & 363 & 506 \\
\hline C.truncatum & TM9 & & ngor & 132 & & 547 & & 64 & 507 \\
\hline C.truncatum & CTM10* & Lentil & langor & JX971133 & $\mathrm{KC} 1$ & KC109548 & KC109588 & 5365 & 9508 \\
\hline C.truncatum & CTM11* & ea & & 1134 & 69 & 549 & 89 & 366 & 509 \\
\hline C.truncatum & CTM12* & bean & & 135 & 470 & 550 & 590 & JX & 510 \\
\hline C.truncatum & TM13 & ima bean & & 1136 & $\mathrm{KC}$ & KC109551 & 591 & $\mathrm{JX}$ & 511 \\
\hline C.truncatum & TM14* & ean & & 137 & 772 & 52 & 92 & $\mathrm{~J} X$ & 512 \\
\hline C.truncatum & TM15 & & & 138 & 73 & & 593 & & 513 \\
\hline C.truncatum & СTM16* & ean & & 139 & 474 & $\mathrm{KC}$ & 594 & $\mathrm{JX}$ & 514 \\
\hline C.truncatum & TTM17 & & & 140 & & & & & 515 \\
\hline C.truncatum & & & & & & & & & 516 \\
\hline truncatum & TM19 & an & & 142 & 77 & 57 & 97 & & 517 \\
\hline C.truncatum & TM20* & & & & & & & & \\
\hline truncatum & TM21 & & & 44 & 79 & 59 & 99 & $\mathrm{~J}\rangle$ & 519 \\
\hline C.truncatum & TM22 & & & 145 & & & & & 520 \\
\hline C.truncatum & TM23 & S & gor & 146 & & & & & 521 \\
\hline truncatum & CTM24* & $\mathrm{ea}$ & gor & 147 & 82 & 62 & 602 & $\mathrm{~J} X$ & 522 \\
\hline C.truncatum & CTM25 & & gor & 148 & 83 & 63 & 603 & 80 & 523 \\
\hline C.truncatum & CTM26* & & & 1149 & & & 04 & & 524 \\
\hline C.truncatum & TM27 & & gor & 150 & 85 & 65 & 505 & & 525 \\
\hline C.truncatum & CTM28* & & & & & & & & 526 \\
\hline truncatum & TM29 & & & 152 & & & & & 527 \\
\hline C.truncatum & СТM30* & ean & ng & 153 & $\mathrm{KC}$ & 68 & 508 & $\mathrm{JX}$ & 528 \\
\hline C.truncatum & TTM31 & & & & & & 509 & & 529 \\
\hline C.truncatum & СТM $32^{*}$ & an & & 155 & & & 610 & & 530 \\
\hline C.truncatum & CTM33 & & & 156 & 91 & 71 & 11 & & 531 \\
\hline truncatum & TTM34 & & & & & & & & 532 \\
\hline C.truncatum & CTM35 & aged bean & lang & JX971158 & $\mathrm{KC}$ & 73 & 13 & $\mathrm{JX}$ & 533 \\
\hline C.truncatum & CTM36* & bean & & & & & 14 & & 534 \\
\hline C.truncatum & СТM37 & Chickpea & langor & JX971160 & & & 615 & JX & 535 \\
\hline C.truncatum & CTM38* & Chickpea & angor & JX971161 & $\mathrm{KCl}$ & 76 & $\mathrm{KC}$ & $\mathrm{JX}$ & 536 \\
\hline C.truncatum & СТМ39 & Chickpea & langor & JX971162 & & & 617 & & 537 \\
\hline C.truncatum & CTM40* & Chickpea & gor & 163 & & 578 & 618 & & 538 \\
\hline C. dematium & CDM41 & Cowpea & Selangor & JX567506 & & 429 & 425 & 433 & 437 \\
\hline C. dematium & CDM42* & Cowpea & Selangor & JX567507 & JX669442 & JX669430 & JX669426 & & 9438 \\
\hline C. dematium & $\mathrm{CDM}_{43}{ }^{*}$ & Cowpea & Selangor & JX567508 & JX669443 & JX669431 & JX669427 & JX66 & JX669439 \\
\hline C. dematium & CDM $44^{*}$ & Cowpea & Selangor & JX567509 & JX669444 & JX669432 & JX669428 & JX6 & 9440 \\
\hline C. gloeosporioides & CGM45* & oybean & Selangor & JX669445 & JX827449 & JX827431 & 7437 & $\mathrm{JX8}$ & 7443 \\
\hline C. gloeosporioides & CGM46* & Soybean & Selangor & & & & JX827438 & JX827426 & JX827444 \\
\hline C. gloeosporioides & CGM47 & Soybean & Selangor & JX669447 & JX827451 & JX827433 & JX827439 & JX827427 & JX827445 \\
\hline C. gloeosporioides & CGM48* & Soybean & Selangor & JX669448 & JX827452 & JX827434 & JX827440 & JX827428 & JX827446 \\
\hline C. gloeosporioides & CGM49* & Soybean & Selangor & JX669449 & $\mathrm{JX} 827453$ & JX827435 & JX827441 & JX827429 & JX827447 \\
\hline C. gloeosporioides & CGM50* & Soybean & Selangor & JX669450 & JX827454 & JX827436 & JX827442 & JX827430 & JX827448 \\
\hline
\end{tabular}

*The Colletotrichum spp. isolates selected for ISSR, RAPD and phylogenetic analysis. 
the surface of 9-cm diameter petri plates containing water agar, followed by incubation overnight at $25^{\circ} \mathrm{C}$. Then single germinated conidia were transferred with a sterilized needle into PDA media for further study. Each isolate was purified by single spore culture and incubated at $25 \pm 2^{\circ} \mathrm{C}$ for 1 week. A standard method, based on the procedure described by Cai et al. (2009) was applied to survey fungi grown on PDA. After purification and sporulation the fungi were identified based on morphological characteristics (Mordue, 1971; Sutton, 1992). Pure cultures of isolates were stored at $4^{\circ} \mathrm{C}$ on sterilized stems of host plants or on desiccated filter paper. The Colletotrichum spp. isolates were deposited in the University Putra Malaysia collection centre (UPMCC).

DNA extraction. Mycelium from each isolate was grown in $50 \mathrm{ml}$ volumes of potato dextrose broth in $250 \mathrm{ml}$ flasks incubated on a rotary shaker $(150 \mathrm{rpm})$ at $25 \pm 2^{\circ} \mathrm{C}$ for 3 days. The mycelium was harvested by filtration and washed with sterile-distilled water. Total genomic DNA was extracted from all isolates using a modification of the CTAB method described by Talbot (2001). The mycelium was ground into a fine powder under liquid nitrogen and suspended in $500 \mu 1$ extraction buffer. The slurry was incubated for 30 minutes at $65^{\circ} \mathrm{C}$ in $1.5 \mathrm{ml}$ micro centrifuge tubes. DNA samples were purified with equal volumes of Chloroform: Iso-amyl Alcohol (24:1) mixture, and precipitated with Iso-propanol. The tubes were centrifuged at $13000 \mathrm{rpm}$ (Eppendorf Centrifuge) for 10 minutes and DNA pellets were rinsed with $70 \%$ ethanol, air dried, suspended in $\mathrm{ddH}_{2} \mathrm{O}$ or TE buffer $(\mathrm{pH} 8.0)$ and stored at $-20^{\circ} \mathrm{C}$ for further use.

PCR Amplification and DNA Sequencing. The multigene loci, from 50 Colletotrichum spp. isolates were amplified using the primers listed in Table 2. The primers were synthesized at First Base Laboratories Sdn Bhd, Selangor, Malaysia. The PCR amplication was performed in final reaction volume of $25 \mu \mathrm{l}$ containing $1 \mathrm{X}$ PCR buffer, $2 \mathrm{mM}$ $\mathrm{MgCl}_{2}, 0.2 \mathrm{mM}$ each dNTP, $0.5 \mathrm{mM}$ each primer, $1 \mathrm{U}$ taq polymerase (Fermentas Co. Biosyntech Sdn Bhd, Selangor, Malaysia) and $10 \mathrm{ng}$ of template DNA. The amplification was performed in a programmable (BioRad iCycler) thermo-cycler using the following thermal program: $94^{\circ} \mathrm{C}$ for $4 \mathrm{~min}$; followed by 35 cycles of denaturation at $94^{\circ} \mathrm{C}$ for $40 \mathrm{~s}$, annealing $30 \mathrm{~s}$ at $59^{\circ} \mathrm{C}$ for actin, histone and $\beta$-tubulin, $56^{\circ} \mathrm{C}$ for GPDH and CHS I, and $53^{\circ} \mathrm{C}$ for ITS, elongation at $72^{\circ} \mathrm{C}$ for $1 \mathrm{~min}$; and a final extention step of $72^{\circ} \mathrm{C}$ for $7 \mathrm{~min}$. All PCR reactions were performed in duplication. PCR products were monitored by staining with ethidium bromide on $1 \%$ agarose electrophoresis gels in $1 \times \mathrm{TAE}$ buffer (10 mM Tris; $1 \mathrm{mM}$ EDTA; $\mathrm{pH}$ 8.0) at $70 \mathrm{~V}$ for $45 \mathrm{~min}$. at room temperature and visualized under UV light and photographed using gel documentation system (GeneSnap Ver 6.03, Syngene Laboratories, Cambridge, United Kingdom). The size of amplified DNA regions was estimated by comparison with GeneRuler ${ }^{\mathrm{TM}} 1 \mathrm{~Kb}$ DNA ladder and Gene Ruler $^{\mathrm{TM}} 100$ bp kb DNA ladder (Fermentas Co. Biosyntech Sdn Bhd, Selangor, Malaysia). PCR products from each isolate were purified using the Gene JET ${ }^{\mathrm{TM}}$ PCR Purification

Table 2. Primers used for PCR amplification and DNA sequencing

\begin{tabular}{|c|c|c|c|}
\hline Gene & Primer & Sequences of Primers & Reference \\
\hline \multirow[t]{2}{*}{ ITS } & ITS5 & 5'-GGAAGTAAAAGTCGTAACAAGG-3' & White et al., 1990 \\
\hline & ITS4 & 5'-TCCTCCGCTTATTGATATGC-3' & \\
\hline \multirow[t]{2}{*}{ Actin } & ACT-512F & 5'-ATGTGCAAGGCCGGTTTCGC-3' & Carbone and Kohn., 1999 \\
\hline & ACT-783R & 5'-TACGAGTCCTTCTGGCCCAT-3' & \\
\hline \multirow[t]{2}{*}{ Chitin } & CHS I-79F & 5'-TGGGGCAAGGATGCTTGGAAGAAG-3' & Carbone et al., 2003 \\
\hline & CHS I-354R & 5'-TGGAAGAACCATCTGTGAGAGTTG-3' & \\
\hline \multirow[t]{2}{*}{ GPDH } & GDF1 & 5'-GCCGTCAACGACCCCTTCATTGA-3' & Guerber et al., 2003 \\
\hline & GDR1 & 5'-GGGTGGAGTCGTACTTGAGCATGT-3' & \\
\hline \multirow[t]{2}{*}{$\beta$-tubulin } & $\mathrm{T} 1$ & 5'-AACATGCGTGAGATTGTAAGT-3' & O’Donnell and Cigelnik, 1997 \\
\hline & $\mathrm{Bt} 2 \mathrm{~b}$ & 5'-ACCCTCAGTGTAGTGACCCTTGGC-3' & Glass and Donaldson 1995 \\
\hline \multirow[t]{2}{*}{ Histone } & CYLH3F & 5'-GCAACATCTCGTCCGCTCT-3' & Crous et al., 2004 \\
\hline & CYLH3R & 5'-TGAAGTGGGGAGAAGGGAA-3' & \\
\hline
\end{tabular}


Kit, according to the manufacturer's instructions. DNA sequencing in both directions using forward and reverse primers was performed by commercial sequencing service provider (First BASE Laboratories Sdn Bhd, Selangor, Malaysia).

Phylogenetic Analysis. Phylogenetic analysis was performed using sequences of multigene loci. The accession numbers of all gene sequences are listed in Table 1. DNA sequences of each isolate was refined using BioEdit Sequence Alignment Editor (Hall, 1999) in which the sequences obtained from reverse primer was transformed to reverse complement and aligned with the sequence obtained from forward primer to obtain consensus sequence. The consensus sequence of isolates was aligned using the CLUSTAL W Multiple Sequence Alignment program (http://www.ebi. ac.uk/Tools/services/web) (Thompson et al., 1994) and optimized manually to explore the nucleotide variability among isolates. Blast alignment was conducted to identify the isolates and analyses the homology of these sequences with the same species sequences available in the GenBank database at the National Center for Biotechnology Information (NCBI) (http://ww.ncbi.nlm.nih.gov/BLAST) (Benson et al., 2008). The sequence alignments were analyzed to design the evolutionary history relations based on distance method using the maximum parsimony (MP) and neighbor-joining (NJ) in MEGA 5 software version 5110426 (Tamura et al., 2011). Ambiguously aligned regions were excluded from analyses. Branch support of the trees obtained from maximum parsimony analysis was assessed by bootstrapping with 1000 replications to estimate the reliability of inferred monophyletic groups. All positions containing gaps and missing data were treated as missing data. DNA sequences of Colletotrichum lindemathianum strain CBS 151.28 from Phaseolus vulgaris, which all multigene sequences of this strain was available in GenBank was used as the designated out-group in all analyses. Some reference sequences were obtained from GenBank i.e. specimen type of each species, and used to figure the phylogeny tree of single and combined multigene sequences.

Amplification and ISSR-PCR. The ISSR-PCR was performed using selected UBC primers (University of British Columbia, Vancouver, Canada) (UBC 808, UBC 810, UBC 820, UBC 834, UBC 841, UBC 864 and UBC112) based on the results of initial screening against a set of representative studied isolates. The UBC primers were used and found to produce good quality banding patterns. The primers were synthesized at First BASE Laboratories Sdn Bhd,
Selangor, Malaysia. Details for the ISSR PCR procedure, reaction mixture and analysis of PCR products were the same as for samples included in RAPD reactions with the exception of the 12-25mer primers known as intersequence repeats (Zietkiewicz et al., 1994). Amplification reactions were performed using a programmable (BioRad iCycler) thermo-cycler in volumes of $25 \mathrm{ml}$ containing $0.5 \mu \mathrm{M}$ primer, $1.5 \mathrm{mM} \mathrm{MgCl}, 0.2 \mathrm{mM}$ of each dNTP, 1 U Taq DNA polymerase (Fermentas Co. Biosyntech Sdn Bhd, Selangor, Malaysia) and $10 \mathrm{ng}$ of template DNA. Polymerase chain reactions (PCR) were carried out with an initial denaturation for $4 \mathrm{~min}$ at $94^{\circ} \mathrm{C}$ followed by 35 cycles of $1 \mathrm{~min}$ of denaturation at $94^{\circ} \mathrm{C}, 1 \mathrm{~min}$ of annealing temperature from $50{ }^{\circ} \mathrm{C}$ to $60^{\circ} \mathrm{C}, 1.5 \mathrm{~min}$ of extension at $72^{\circ} \mathrm{C}$ and the final extension at $72^{\circ} \mathrm{C}$ for 10 minutes. All PCR reactions were performed in two replications to confirm the consistency of amplification.

ISSR analysis. The sizes of amplified DNA fragments were measured using UVIDod (version 99.02) by comparison with a $2-\log$ DNA ladder $(0.1-1 \mathrm{~kb})$ marker. The steady amplified DNA bands were scored as 0 for absence and 1 for presence of DNA bands. Singleton loci (bands occurring only once) and weak, irreproducible bands were not included in the dataset. All datasets were combined to produce a 116-locus genotype for each individual DNA accession. The scores were used to create a data matrix to analyse genetic relationship. The ISSR-PCR fragment profiles of all the isolates were subjected to cluster analysis to produce a dendrogram based on Jaccard's similarity coefficient by Un-weighted Pair Group Method (UPGMA) using NTSYSpc program version 2.02 (Exeter Software, New York, NY, USA) described by Rohlf (1993). Grouping of isolates according to genetic analysis were assessed separately for ISSR and RAPD markers and results were compared within each marker group.

Amplification condition of RAPD. Random amplification of polymorphic DNA was conducted using single stranded oligonucleotides based on the results of initial screening of Operon decamer primers (designed by Operon Technologies, Alameda, USA) against a set of representative studied isolates. The Operon primers were used and found to produce good quality and reproducible banding patterns for all representative samples. RAPD primers (single stranded oligonucleotides ten bases long) were designed based on the criteria of random sequence, absence of palindromes, and $>50 \%$ GC content, and synthesized at First BASE Laboratories Sdn Bhd, Selangor, Malaysia. Each primer was used to attempt to amplify the DNA from a set of 24 
isolates of Colletotrichum spp., and reagent concentrations and amplification conditions were adjusted empirically until amplification was achieved and different amplicons between the isolates were observed. Amplification reactions were conducted in a programmable (BioRad iCycler) thermocycler in volumes of $25 \mathrm{ml}$ containing $0.5 \mu \mathrm{M}$ primer, 2.5 of a $10 \times$ buffer $(200 \mathrm{mM}$ Tris-HCl, $500 \mathrm{mM} \mathrm{KCl}), 1.5 \mathrm{mM}$ $\mathrm{MgCl}_{2}, 0.2 \mathrm{mM}$ of each dNTP, $1 \mathrm{U}$ Taq DNA polymerase (Fermentas Co. Biosyntech Sdn Bhd, Selangor, Malaysia) and $2 \mu \mathrm{l}$ of DNA template (10 ng). PCR amplification was performed as described by Williams et al. (1990) with some modifications. Polymerase chain reactions (PCR) were carried out with an initial denaturation for $4 \mathrm{~min}$ at $94^{\circ} \mathrm{C}$ followed by 45 cycles of $1 \mathrm{~min}$ of denaturation at $94^{\circ} \mathrm{C}, 1$ min of annealing temperature at $36^{\circ} \mathrm{C}, 2$ min of extension at $72^{\circ} \mathrm{C}$, and the final extension at $72^{\circ} \mathrm{C}$ for 10 minutes. A PCR negative control, consisting of $2 \mu \mathrm{l}$ distilled water instead of $2 \mu \mathrm{l}$ DNA, was included in each PCR run. Only primers that generated polymorphic patterns of amplified products between Colletotrichum species were retained for a second round of screening. All PCR reactions were performed in two replications to confirm the consistency of amplification.

RAPD analysis. Randomly amplified polymorphic DNA markers were included as second set of markers for analysis of the Colletotrichum spp. genome and for comparison with ISSR results. RAPD bands were scored as present (1) and absent (0). Singleton loci (bands occurring only once) and weak, irreproducible bands were not included in the dataset. All datasets were combined to produce a 116-locus genotype for each individual DNA accession. The sizes of amplified DNA fragments were measured using UVIDod (version 99.02) by comparison with 2-Log DNA ladder $(0.5-10 \mathrm{~kb})$ markers. Data were analyzed using the numerical taxonomy package NTSYS-pc version 1.80 (Rohlf, 1993). A similarity matrix was produced with the UPGMA program using Jaccard's distance coefficient which measures the proportion of band mismatches between pairs of isolates. Based on the RAPD banding patterns, dendrograms were generated from 7 RAPD primer amplifications. Cluster analysis was performed through the SAHN cluster program using the branches of the dendrogram obtained with 1000 replications through the program NTSYS-pc version1.80 (Rohlf, 1993).

Gel electrophoresis and staining. PCR products were monitored by staining with ethidium bromide on $1 \%$ agarose electrophoresis gels in $1 \times$ TAE buffer $(10 \mathrm{mM}$ Tris; $1 \mathrm{mM}$ EDTA; $\mathrm{pH} \mathrm{8.0)}$ at $70 \mathrm{~V}$ for $45 \mathrm{~min}$. at room temperature and visualized under UV light and photographed using gel documentation system (GeneSnap Ver 6.03, Syngene Laboratories, Cambridge, United Kingdom). as described by Sambrook (Sambrook et al., 1989). The size of amplified DNA regions was estimated by comparison with Gene Ruler $^{\mathrm{TM}} 1 \mathrm{~Kb}$ DNA ladder and Gene Ruler ${ }^{\mathrm{TM}} 100$ bp kb DNA ladder (Fermentas Co. Biosyntech Sdn Bhd, Selangor, Malaysia). DNA was quantified by ethidium bromide fluorescence on a UV transilluminator with known quantities of lambda DNA (Sambrook et al., 1989).

\section{Results}

Multigene Sequences Analysis. PCR amplifications of total genomic DNA using primer pairs listed in Table 2 produced a single PCR product with specific size for all genes in all studied species. DNA sequencing confirmed the DNA fragments of actin, chitin, $\beta$-tubulin, histone; glyceraldehyde-3-phosphate dehydrogenase and ITSrDNA from all isolates were equal in length with 291, 299, 788, 412, 292 and $610 \mathrm{bp}$, respectively (http://ww.ncbi. nlm.nih.gov). Molecular approach using BLASTn search by multigene sequences revealed identity of 40 isolates from diverse legume plants as C. truncatum with the DNA similarity range from 98 to $100 \%$, six isolates from soybean as C. gleoesporioides with the high similarity of $99-100 \%$, and four isolates from cowpea as C. dematium with the similarity of more than $99 \%$. DNA sequence comparisons from six genes allowed the verification of identified species of $C$. truncatum, C. dematium and C. gleoesporioides and the identity C. capsici as a synonym of $C$. truncatum in this study.

Based on the matrix distance analysis of multigene sequences, the Colletotrichum species showed diverse degrees of inter- and intraspecific divergence. The distance analysis based on the alignment of the multigene sequences among C. truncatum isolates from diverse host plants ranged from 0.0 to $1.4 \%$. However an intraspecific divergence was obtained with $C$. truncatum, but isolates from the same host had a high rate of DNA homology, irrespective of their origin. The intraspecific nucleotide variability ranged $0.2-0.4 \%$ within $C$. gloeosporioides and $C$. dematium. The greatest nucleotide variation was recorded between $C$. truncatum and C. gloeosporioides (19.0-19.9\%). Isolates of C. gloeosporioides and C. dematium species showed high divergence values (17.0-17.5\%), and the least interspecific nucleotide variability of $15.5-16.1 \%$ was recorded between C. truncatum and C. dematium.

The combined dataset of six genes comprised of 2771 characters after alignment, of which, 985 characters were 


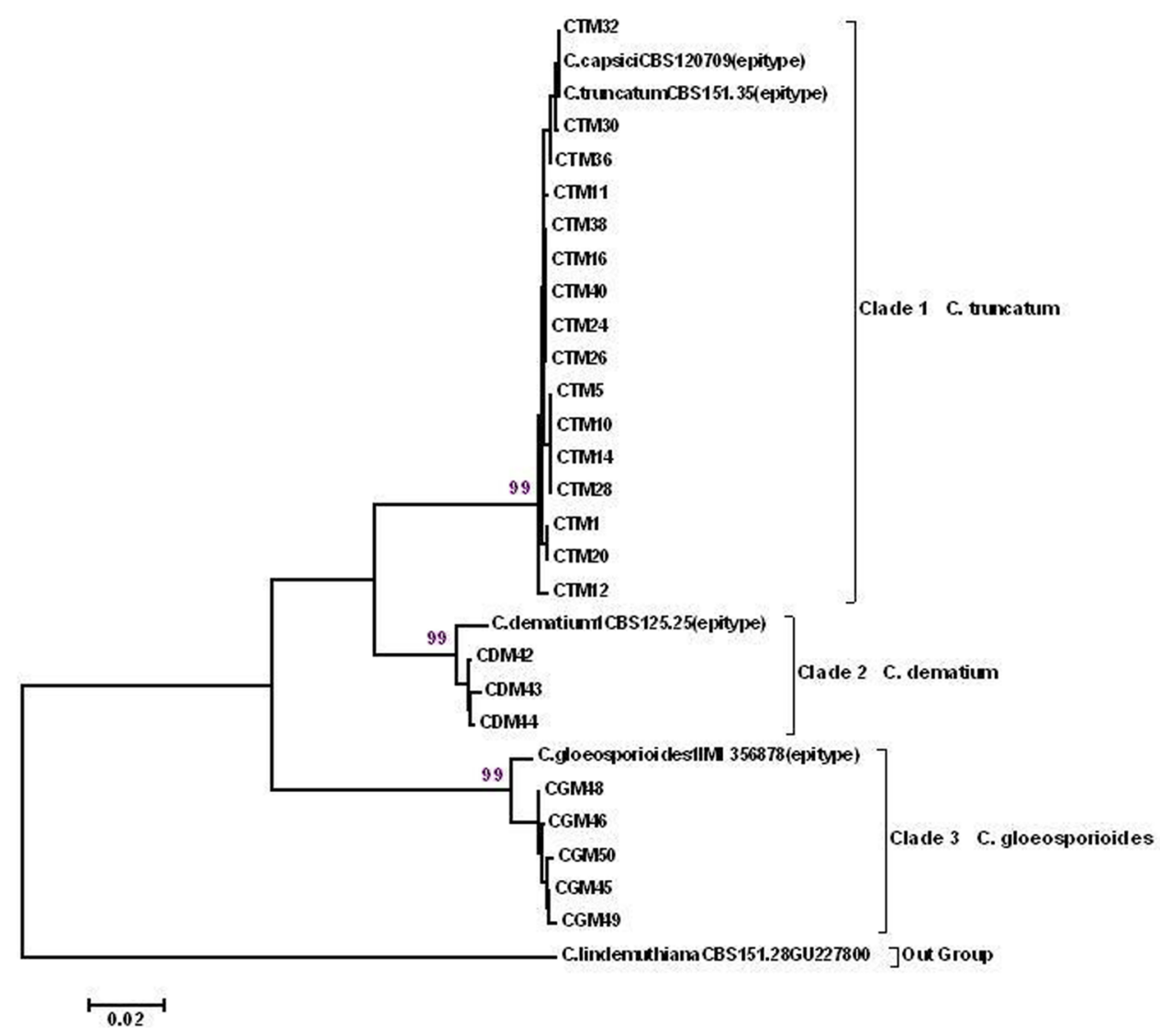

Fig. 1. Maximum parsimony phylogram inferred from multigene sequence data showing phylogenetic relationships among isolates of Colletotrichum from legumes and selected sequences of Colletotrichum species (epitypes). Data analyzed with random addition sequence, unweighted parsimony and treating gaps as missing data. Values above the branches are parsimony bootstrap above $90 \%$. The tree is rooted with Colletotrichum lindemuthianum.

parsimony informative (35.5\%). The phylograms inferred from dataset of combined six gene regions is shown in Fig. 1. The phylograms inferred from single gene Actin, CHS I, $\beta$-tubulin, histone and GPDH showed essentially similar topology as that from ITS-rDNA and combined datasets and are, therefore, not shown. The isolates of Colletotrichum associated with anthracnose in Leguminosae clustered into 3 well-defined clades based on phylograms inferred from multigene sequences, representing three distinct species. The multigene analysis included sequences of epitype isolates of each species based on their availability from the GenBank.

The ISSR-PCR. ISSR primers produced multi band patterns for each of the isolates (Fig. 2). Most of the amplification products were reproducible and a total of 116 score-able loci were produced from the amplified products. The average number of bands per primer was 16.5 which ranged in size from 300 to $2600 \mathrm{bp}$. All 116 of the ISSR alleles were polymorphic; there were no ISSR bands that were fixed (shared by all individuals in this study). The percentage of polymorphic fragments per primer was $100 \%$. A cluster analysis with Unweighted Pair-Group Method (UPGMA) based on Jaccard's similarity coefficient divided Colletotrichum spp. isolates into three main clusters, and each cluster representing each species; $C$. dematium, $C$. gloeosporioides and $C$. truncatum. The clusters differed with a maximum distance matrix of $0.32,0.54$ and 0.57 , respectively (Fig. 3). The first cluster contained isolates CDM42, CDM43 and CDM44 of $C$. dematium species, which were obtained from cowpea.

The isolates CDM44 and CDM43 with the similarity of $86 \%$ differed from CDM42 with a distance matrix of 0.32 . The second cluster included isolates of $C$. gloeosporioides from soybean with a distance of 0.16 to 0.54 , and the similarity 0.46 to 0.84 . These isolates clustered into two sub-clusters with maximum distance matrix of 0.54 . The last cluster included C. truncatum isolates from diverse host plants and isolates from cowpea; chickpea, country bean 


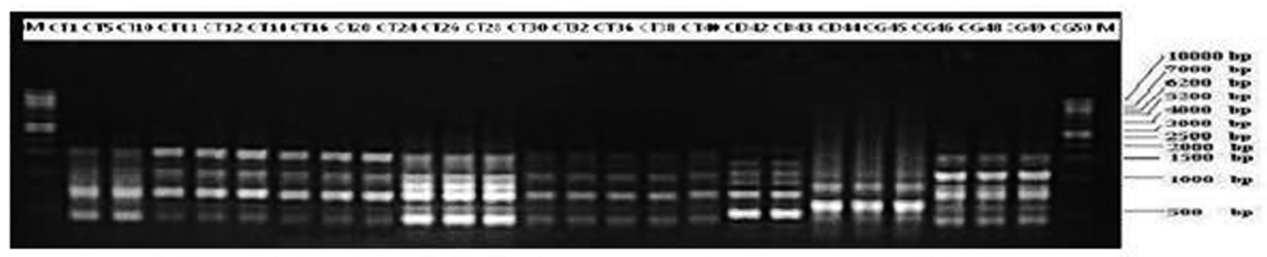

$\mathrm{UBC}$ SOS

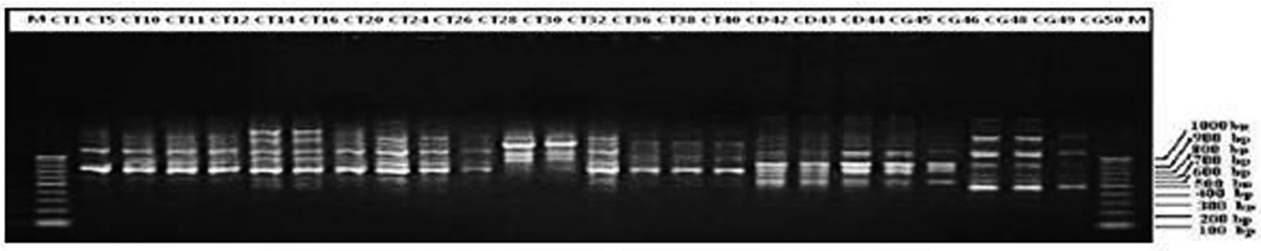

$\mathrm{UBC} \$ 34$

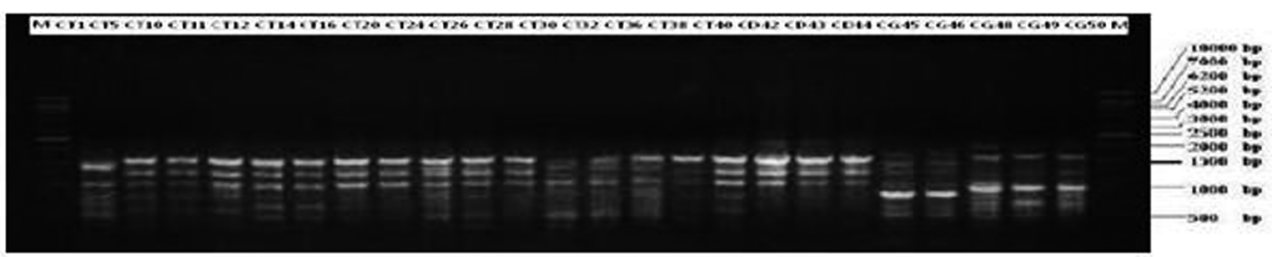

UBC $\$ 10$

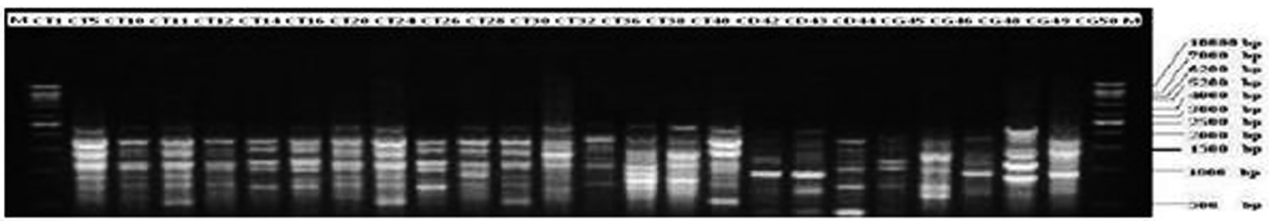

UBC 112

Fig. 2. Gel electrophoresis of amplification products from Colletotrichum spp. genomic DNA obtained by ISSR primers UBC 808, UBC 834, UBC 810 and UBC 112, respectively. The $1^{\text {st }}$ and the last lanes (M) are 2-log DNA ladder. Lanes 1 to 16 represent the representative isolates of $C$. truncatum. Lanes 17 to 21 represent the representative isolates of $C$. gloeosporioides and Lanes 22 to 24 represent the representative isolates of $C$. dematium.

and winged bean with a maximum distance of 0.57 . Cluster 3 was divided into five sub-clusters with a distance matrix ranging from 0.25 to 0.57 . Percent polymorphism per species ranged from a low of 32 percent in the $C$. dematium individuals $(\mathrm{N}=3)$, to a high of 57 percent in the $C$. truncatum $(\mathrm{N}=15)$. The sub-cluster A contained 3 isolates CTM1, CTM5 and CTM10 collected from soybean, bean and lentil, respectively, with a maxim distance of 0.28 . The subcluster B consisted of four isolates CTM14, (CTM16 and CTM20) and CTM24 collected from bean, soybean and cowpea, respectively, with a maxim distance of 0.41 . The sub-cluster $\mathrm{C}$ comprised of 2 C. truncatum isolates recovered from pea and lima bean, respectively, with a maxim distance of 0.41 . The isolates CTM6, CTM28 and CTM30 collected from bean, soybean and country bean, respectively, constituted the sub-cluster $\mathrm{D}$ with a maxim distance of 0.24 . The isolates CTM30 and CTM36 from winged bean and the isolates CTM38 and CTM40 from chickpea made up sub-cluster E, with similarity ranging from 0.63 to 0.89 with a maxim distance of 0.27 . The minimum and maximum percent similarities among the C. truncatum, C. dematium and C. gloeosporioides ranged from 0.43 to $0.89,0.68$ to 0.86 and 0.46 to 0.84 .

ISSR analysis performed in this study showed $C$. truncatum isolates had less variation with $C$. gloeosporioides isolates than $C$. dematium. Results from the phylogram exhibited a clear distinction between species, thereby, supporting results from phylogenetic analysis and DNA sequences of multigene loci studies. The use of ISSR markers authorized knowledge of genetic structure within and among the 


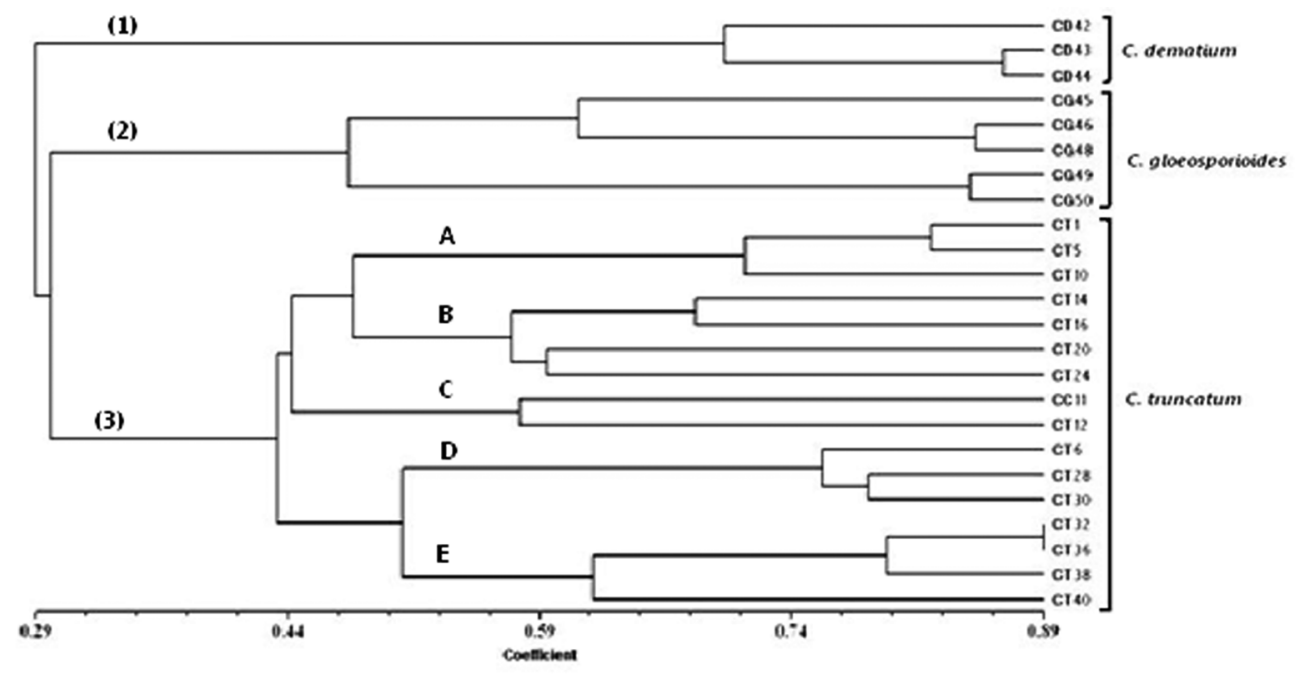

Fig. 3. Dendrogram constructed by ISSR primers showing the genetic relationships among representative isolates of Colletotrichum spp. [derived from Unweighted Pair-Group (UPGMA) cluster analysis, based on Jaccard's similarity coefficient].

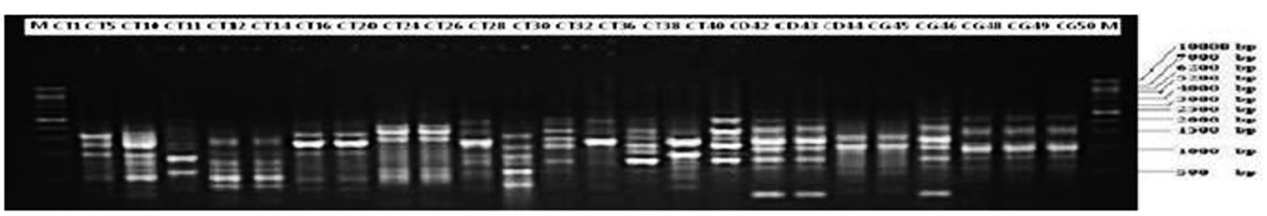

OPA-11

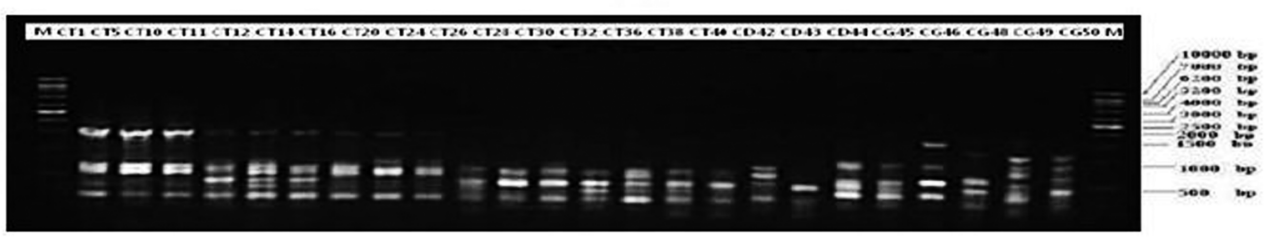

OPA-O1

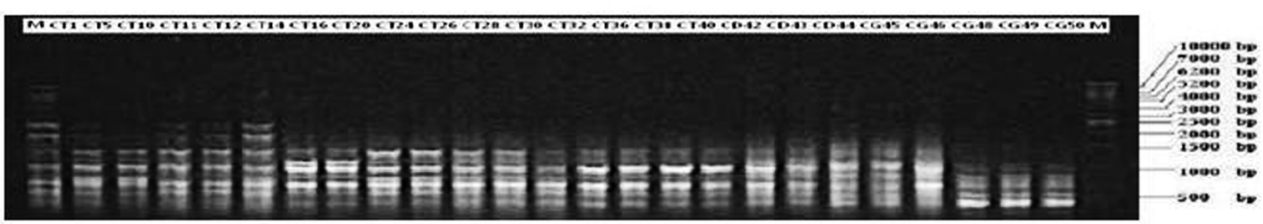

OPJ-20

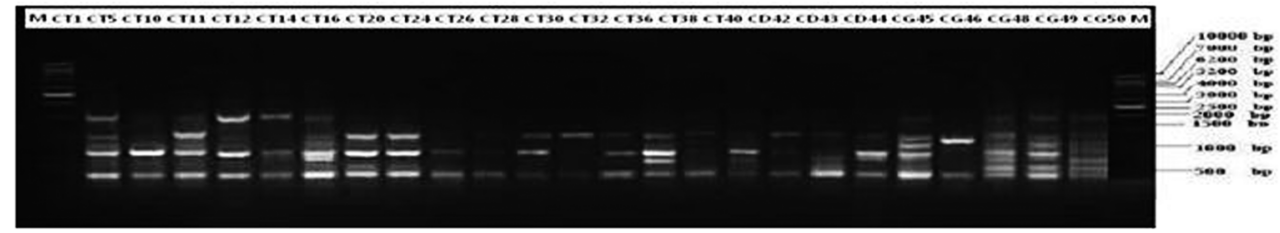

OPA- 09

Fig. 4. Gel electrophoresis of amplification products from Colletotrichum spp. genomic DNA obtained by RAPD primers OPA11, OPA-01, OPJ-20 and OPA-09, respectively. The $1^{\text {st }}$ and the last lanes (M) are 2-log DNA ladder. Lanes 1 to 16 represent the representative isolates of $C$. truncatum. Lanes 17 to 21 represent the representative isolates of $C$. gloeosporioides and Lanes 22 to 24 represent the representative isolates of C.demtium. 


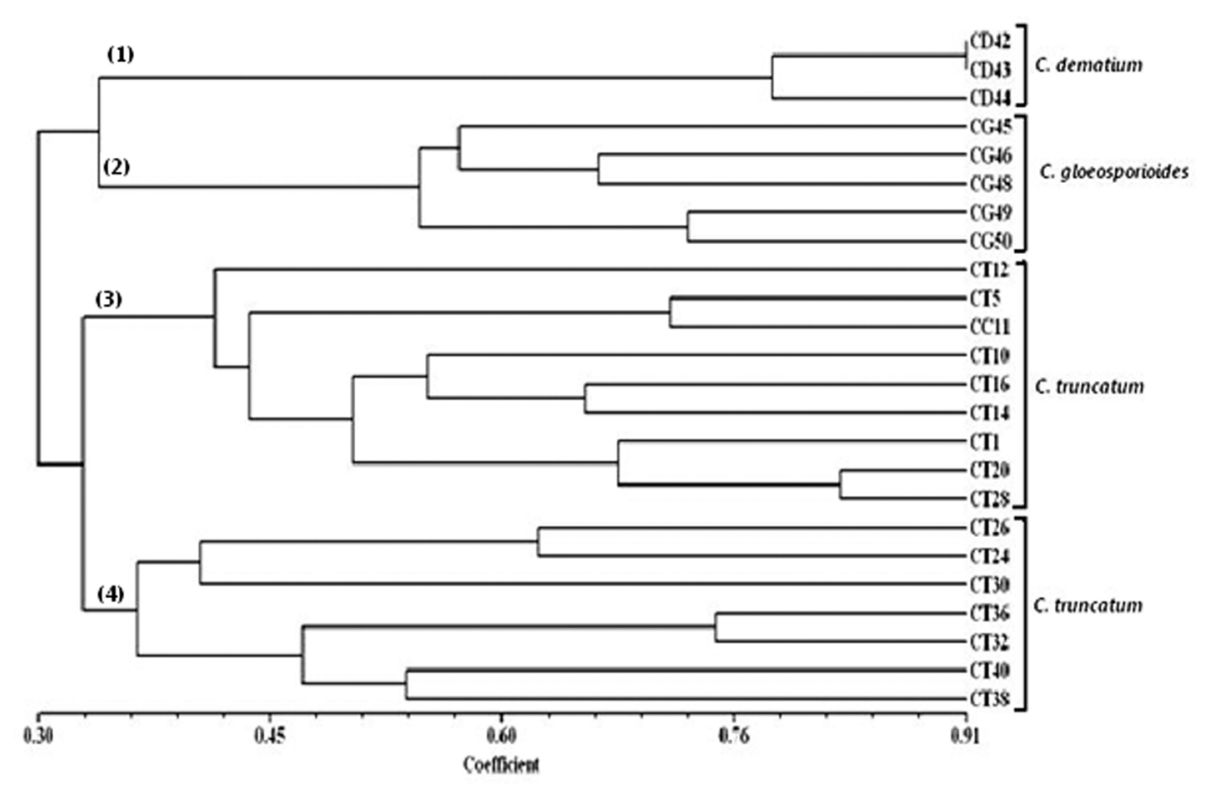

Fig. 5. Dendrogram constructed by RAPD primers showing the genetic relationships among representative isolates of Colletotrichum spp. [derived from Unweighted Pair-Group (UPGMA) cluster analysis, based on Jaccard's similarity coefficient].

Colletotrichum species. The performance of ISSR and RAPD as marker systems was evaluated by their efficiency for inter and intraspecific polymorphism detection and ability to show genetic relationship. ISSR and RAPD-based DNA fingerprinting could be applied for studding genetic diversity between Colletotrichum spp. from legume in the absence of a certain differential set.

The RAPD-PCR. Twenty-four isolates representing three species of Colletotrichum from diverse host plants from Leguminosae were compared using randomly amplified polymorphic DNA (RAPD) markers. The RAPD-PCR was performed using selected primers based on the results of initial screening of a group of primers against a set of representative studied isolates. The RAPD primers were used and found to produce good quality banding patterns. RAPD primers produced multi band patterns for each of the isolates, and examples of RAPD markers generated by the primers are shown in Fig. 4. Most of the amplification products were reproducible and a total of 106 score-able markers were generated from the amplified products, 2 of which were monomorphic for all taxa. All implications were repeated twice, and both faint and intense bands were scored if shown to be reproducible in separate runs. The average number of bands per primer was 15 which ranged in size from 100 to $2700 \mathrm{bp}$. Most of the amplified DNA bands generated from ISSR primer bands were polymorphic. The percentage of polymorphic fragments per primer was 96\%. A cluster analysis with Unweighted Pair-
Group Method (UPGMA) based on Jaccard's similarity coefficient separated Colletotrichum spp. isolates into four distinct clusters, and each cluster representing each species; C. truncatum, C. gloeosporioides and C. dematium (Fig. 5). The first cluster contained isolates CDM42, CDM43 and CDM44 of $C$. dematium species from cowpea. Isolates of soybean-infecting species of $C$. gloeosporioide comprised of cluster 2 . The third and fourth clusters contained diverse host legume-infecting isolates of $C$. truncatum.

The isolates of C. truncatum yielded RAPD markers distinctly different from each other and from the other species in the initial analysis. A similarity matrix was generated with 106 RAPD markers, including those from $C$. truncatum, $C$. dematium and C. gloeosporioides isolates. The UPGMA cluster analysis showed that the $C$. truncatum isolates from diverse host plants had a low level of similarity (approx. 32\%) to the other isolates of $C$. dematium and $C$. gloeosporioides. Within the first group, the CDM42 and CDM 43 isolates and CDM45 were separated at approximately the $78 \%$ level. The clusters $1(C$. dematium) and 2 (C. gloeosporioides) were separated at less than the $32 \%$ level. The $C$. gloeosporioides isolates were divided into two sub-clusters at the $54 \%$ level. Isolates of $C$. truncatum from diverse host plants were divided into cluster 3 and cluster 4 at 32\% level. The level of diversity among isolates from the diverse host species showed a high level of diversity (10-60\%). The isolates from cowpea, chickpea, country bean and winged bean that had previously been identified as $C$. capsici was placed in a distinct cluster with similarity at $38-91 \%$ level. The $C$. truncatum isolates in 
cluster 4 also exhibited a relatively low level of similarity at $43-91 \%$ level.

Index of efficiency rate of ISSR and RAPD markers. The effective maker ratio (EMR) or the number of polymorphic products from a single PCR reaction was calculated as 16.5 for the ISSR, and 15 for the RAPD markers. Expected percent polymorphic loci are statistical computations often used to gauge levels of genetic diversity. The estimates of expected percent polymorphism were higher in ISSR than in RAPD. Dominant markers, like ISSR and RAPD only have two possible alleles at each locus (band present or band absent) and therefore a maximum expected heterozygosity of 0.5 . Private alleles, or alleles that are unique to certain species or geographic area, can be particularly useful in comparing diversity between invasive species, native and introduced. Results between markers were congruent, but the effective maker ratio and subsequent to that the number of private alleles was greater in ISSR markers. The overall patterns of population genetic structure were consistent across markers. Population structure within and among species was found to be relatively different among geographical regions, and diverse host plants from which isolates were collected. It would seem that this pattern was robust, as it was supported by both marker systems. The consistency between individual-based UPGMA trees constructed using the ISSR and RAPD database was obvious. The ISSR tree showed individuals from the same species and sampling sites occurring in the same clades occasionally, while the RAPD-based tree was partially different. Both the effective maker ratio and the number of private allele's index were higher for ISSRs than they were in RAPD. These statistics quantify the amount of usable data obtained per unit effort for each method, and the results indicate that ISSRs were more efficient DNA fingerprints to use in genetic diversity. This result was mainly based on the EMR, or the number of polymorphic products per polymerase chain reaction. Single ISSR reactions in this study resulted in more than 17 alleles, while 15 alleles at most could be observed from a single RAPD reaction, and hence well RAPDs tend to be less repeatable than ISSRs markers.

\section{Discussion}

DNA sequence data from Multigene loci differentiated Colletotrichum spp. into three species of $C$. truncatum, $C$. dematium and C. gloeosporioides from leguminous plants in Malaysia. Each taxon was uniquely characterized by the molecular analysis of the multigene sequences. For phylogenetic analysis, epitype species of C. truncatum
(CBS 151.35), C. dematium (CBS 125.25) and $C$. gloeosporioides (1IMI 356878) from the GenBank were included in this study. In all molecular studies especially in phylogenitic analysis and to design phylogenetic tree, using type specimens or epitype should be considered. Where possible, all strains should be compared against the recently designated epitype of Colletotrichum spp. to establish if they are correctly named (Cannon et al., 2012; Crouch et al., 2009; Damm et al., 2009; Hyde et al., 2009a; Hyde et al., 2009b). The combined data of six genes including actin, chitin, $\beta$-tubulin, ITS-rDNA, histone and GAPDH comprised of 2771 characters after alignment, of which 985 characters were parsimony informative (35.5\%). The combined data represented three well-supported distinct phylogenetic clades (bootstrap $>99 \%$ ), representing distinct species of $C$. truncatum, $C$. dematium and $C$. gloeosporioides, and the data concurred with the standard characters required for the rank of phylogenetic species proposed by Taylor et al. (2000).

The phylograms inferred from neihbour-joining showed essentially similar topology as that from parsimony method (data not shown). The differentiation rested on a single or few base mutations in the multigene sequences. The large majority of polymorphisms were synonymous substitutions, thus the amino acid sequences were identical for all gene sequences. In the present study, histone, GAPDH, $\beta$-tubulin, actin, chitin and ITS-rDNA regions, respectively, contained the most phylogenetically informative characters among closely related taxa. The maximum Parsimony Informative Characters (PIC: 69) and minimum (PIC: 16.5) belonged to the histone and ITS regions, respectively, suggesting that the histone and GAPDH loci with high number of polymorphic nucleotide site can be used in phylogenetic studies to build highly resolved phylogenies at the intraspecific level and closely related species.

Limited research regarding Colletotrichum spp. isolates across legumes has restricted our understanding of population variability and epidemiology. Furthermore, knowledge of what role such diversity may play in resistance breeding and the efficacy of disease control strategies has not been addressed. The research was aimed at identifying and characterizing diversity among Colletotrichum spp. isolates according to genotypic characters. Genetic diversity among isolates of Colletotrichum spp. was assessed using RAPD and ISSR markers. The analysis of representative Colletotrichum spp. isolates associated with legume crops using ISSR and RAPD markers supported the categorization of the isolates into three clusters, representing distinct species of $C$. truncatum, C. dematium and C. gloeosporioides. These species were closely related as indicated by their nearly 
genetic relationship, overlapping morphological and cultural characters, pathogenicity and similar habit. ISSR and RAPD analysis have been widely used for studying genetic diversity and relationships, for genetic mapping, DNA fingerprinting and population genetics (Gupta et al., 2010; Jones et al., 1997; Kumar et al., 2010; Williams et al., 1990).

The data suggested high levels of genetic variation among and within species. Considerable intra and inter-specific diversity was identified and such diversity may contribute to observed differences in morphotype traits and disease development in the field. The variability shown by ISSR and RAPD supported the results of pervious study of these species (Ratanacherdchai et al., 2007; Ratanacherdchai et al., 2010), where RAPD and ISSR analysis differentiated isolates of $C$. capsici and C. gloeosporioides collected from chilli into two distinct clear, representing each species. A clear relationship did not find between genetic diversity and geographical origins or pathogenic variability. Polymorphism or genetic diversity can be used to describe any variation among isolates of a locus, regardless of frequency. For example, a locus present in 49 out of 50 isolates is classified as polymorphic despite the fact that the vast majority of isolates are identical at that locus. The ISSR analysis was partially more sensitive than the RAPD analysis, and allowed for differentiation of isolates of $C$. truncatum into distinct branches corresponding to host specificity. The presence of genetically distinct populations of species in accordance with host specificity and inconsistent with geographical origins was indicated by RAPD and ISSR analysis. The high level of polymorphism within and among species may, however be contributed to the fact that isolates were obtained from different host plants and geographical origins, thus reinforcing the hypothesis of diverse hosts being more important than geographical locations. This result was in agreement with that obtained by Ratanacherdchai et al. (2010), where, there was no clear relationship between genetic diversity and geographical areas.

Contrary to this argument was the fact that the C. truncatum isolates CTM1 and CTM5 collected from soybean in Selangor and bean in Pahang had a low polymorphism level of $12 \%$, while the CTM1 and CTM6 isolates both from soybean had high polymorphism level of $52 \%$. It would therefore be unwise to draw any conclusions from the data, other than that the geographic location from which an isolate was obtained did not have an obvious effect on the parts of the pathogen genome amplified by the primers used in this study. Genetic variability of $C$. falcatum the causal agent of sugarcane anthracnose in India using RAPD and ISSR makers revealed a high genetic diversity between isolates, and 25 isolates classified into six clusters (Kumar et al., 2010). Recognizing the possibility that results of the RAPD markers may not be consistent, thus ISSR analysis was used as an independent means of supporting the RAPD data. In addition, we used stringent conditions for annealing primer and template as described by Levi et al. (1993) for the production of reliable RAPD markers.

Smaller isolated populations of $C$. dematium and $C$. gloeosporioides have passed less genetic diversity than larger isolated populations of C. truncatum. The large population of C. truncatum showed greater amounts of genetic diversity and percent polymorphic loci than smaller populations. The level of genetic variation within a species represents a balance between mutation, drift, and natural selection. Genetic variation is generated by mutation and is lost from populations by genetic drift due to finite population size. There are positive correlations between genetic variation and population size. The lack of strong association between genetic diversity and geographic distance, the great genetic difference between two geographically nearest populations or isolates, the substantial level of differentiation among populations or species, and the high level of genetic diversity assigned to genetic drift, all point to low levels of active gene flow. However, the lack of clear distinction between geographical origins and genetic diversity within and among species is still troubling. The information collected in the present study including DNA sequencing and phylogenetic analysis as well as ISSR and RAPD analyses provide convincing evidence that species examined were very distinct morphologically and genetically.

The similarity coefficient for $C$. truncatum isolates recovered from cowpea, chickpea, winged bean and country bean ranged 0.58 to 0.89 . RAPD and ISSR have also shown a high level of similarity between species and high level of diversity among isolates from diverse host plants. The relationship between these species and isolates based on geographical origins are still unclear and warrants further study with more samples from diverse sites. The difficulty in delimiting species of Colletotrichum is directly related to the limited number and variability of morphological characters (Cai et al., 2009; Hyde et al., 2009a; Suttun, 1992). Overlapping morphology has resulted in considerable 'lumping' of species, particularly evident in closely related species (Sutton, 1980), in which only 32 species are recognized from among more than 72 described species.

Clearly, the use of polyphasic approaches including morphological, physiological and molecular techniques, as strongly advocated by Cai et al. (2009), are facilitating a 
better understanding of species limits within the Colletotrichum genus. Polymorphisms of the C. truncatum isolates from different plant species are suggestive of diverse populations with host origin than geographic distance. The presence of a few genetically different populations within isolates of $C$. truncatum was supported by observations in the present study that different host species at a site were often infected. The relatively low similarity coefficients within and among isolates of different species based on RAPD and ISSR analysis provides additional support for genetic variability between the isolates. The estimates of expected percent polymorphism were higher with ISSR than with RAPD markers. Dominant markers, like ISSR and RAPD only have two possible alleles at each locus (band present or band absent) and therefore a maximum expected heterozygosity of 0.5 (Nybom, 2004). Private alleles, or alleles that are unique to certain species or geographic area, can be particularly useful in comparing diversity between invasive species; native and introduced. Private alleles typically occur at low frequency, and rare alleles tend to be lost quickly by genetic drift (Luikart et al., 1998). Results between markers were congruent, but the effective maker ratio and subsequent to that the number of private alleles was greater with ISSR markers. Overall the pattern of population genetic structur was consistent across markers. Qian et al. (2001) found that ISSRs can overestimate the amount of differentiation between closely related species and underestimate the variation between geographically distinct populations when compared to other dominant markers such as RAPD and AFLP. This could mean that other dominant markers may give a different population structure relative to ISSR. Genetically distinct population of C. truncatum, C. dematium and C. gloeosporioides were distinguished by the molecular analyses. ISSR analysis supported the results of RAPD analysis.

The results of the present study indicate that RAPD analysis and ISSR can supplement existing taxonomic characters for distinguishing Colletotrichum species and can provide much-needed information on genetic variability present within taxa. The problem of delimiting discrete species is particularly well-illustrated in the genus Colletotrichum where a paucity of morphological characters has resulted in considerable weight being placed on a very limited number of characters and has resulted in lumping of species with morphologically similar characters. This trend towards synonymizing species of Colletotrichum occurring on different hosts may be masking much of the genetic variability present within the taxa. The use of molecular analysis provided additional characters for assessing genetic variability within the isolates of Colletotrichum. The present research has elucidated the genetic relationships among a group of closely related and morphologically similar Colletotrichum species. Additionally, it has also been shown that molecular analyses provide much additional information to characterize species associated with legumes in Malaysia.

\section{Acknowledgements}

We are thankful to Malaysian Agricultural Research and Development Institute (MARDI) for kindly collaboration in this study. We acknowledge Lab. assistants and coworkers in plant protection department of University Putra Malaysia (UPM) for valuable field trip arrangements and assistance during field samplings.

\section{References}

Benson, D. A., Karsch-Mizrachi, I., Lipman, D. J., Ostell, J. and Wheeler, D. L. 2008. GenBank. Nucleic Acids Res. 36: D25-D30.

Cai, L., Hyde, K. D., Taylor, P. W. J., Weir, B., Waller, J., Abang, M. M., Zhang, J. Z., Yang, Y. L., Phoulivong, S., Liu, Z. Y., Prihastuti, H., Shivas, R. G., McKenzie, E. H. C. and Johnston, P. R. 2009. A polyphasic approach for studying Colletotrichum. Fungal Divers. 39:183-204.

Cannon, P. F., Damm, U., Johnston, P. R. and Weir, B. S. 2012. Colletotrichum-current status and future directions. Stud. Mycol. 73:181-213.

Casimiro, S., Moura, M., Ze-Ze, L., Tenreiro, R. and Monteiro, A. A. 2004. Internal transcribed spacer 2 amplicons as a molecular marker for identification of Peronospora parasitica (crucifer downy mildew). J. Appl. Microbiol. 96: 579-587.

Ciampi, M. B., Meyer, M. C., Costa, M. J. N., Zala, M., McDonald, B. A. and Ceresini, P. C. 2008. Genetic structure of populations of Rhizoctonia solani anastomosis group-1 IA from soybean in Brazil. Phytopathology 98:932-941.

Crouch, J. A., Clarke, B. B., White, J. F. and Hillman, B. I. 2009. Systematic analysis of the falcate-spored graminicolous Colletotrichum and a description of six new species of the fungus from warm season grasses. Mycologia 101:717-732.

Damm, U., Woudenberg, J. H. C., Cannon, P. F. and Crous, P. W. 2009. Colletotrichum species with curved conidia from herbaceous hosts. Fungal Divers. 39:45-87.

Graham, P.H. and Vance, C.P. 2003. Legumes; Importance and Constraints to greater use. Plant Physiol. 131:872-877.

Gupta, S., Srivastava, M., Mishra, G., Naik, P., Chauhan, R., Tiwari, S., Kumar, M. and Singh, R. 2010. Analogy of ISSR and RAPD markers for comparative analysis of genetic diversity among different Jatropha curcas genotypes. Afric. J. Biotechnol. 7:4230-4243.

Guthrie, P. A. I., Magill, C. W., Frederiksen, R. A. and Odvody, G. N. 1992. Random amplified polymorphic DNA markers: 
A system for identifying and differentiating isolates of Colletotrichum. Phytopathology 82:832-835.

Hall, T. A. 1999. BioEdit; a user-friendly biological sequence alignment editor and analysis program for windows 95/98/ NT. Nucleic Acids Symposium Series 41:95-98.

Hettwer, U. and Gerowitt, B. 2004. An investigation of genetic variation in Cirsium arvense field patches. Weed Res. 44: 289-297.

Hyde, K. D., Cai, L., Cannon, P. F., Crouch, J. A., Crous, P. W., Damm, U., Goodwin, P. H., Chen, H., Johnston, P. R., Jones, EBG., Liu, Z. Y., McKenzie, E. H. C., Moriwaki, J., Noireung, P., Pennycook, S. R., Pfenning, L. H., Prihastuti, H., Sato, T., Shivas, R. G., Tan, Y. P., Taylor, P. W. J., Weir, B. S., Yang, Y. L. and Zhang, J. Z. 2009a. Colletotrichum - names in current use. Fungal Divers. 39:147-183.

Hyde, K, D., Cai, L., McKenzie, E. H. C., Yang, Y. L. and Zhang, J. Z. 2009b. Colletotrichum: a catalogue of confusion. Fungal Divers. 39:1-17.

Hyde, K. D. and Zhang, Y. 2008. Epitypification: should we epitypify? Journal of Zhejiang University, Science B 9:842846.

Jones, C. J., Edwards, K. J. S., Castaglione, S., Winfield, M. O. and Sala, F. et al. 1997. Reproducibility testing of RAPD, AFLP, and SSR markers in plants by a network of European laboratories. Molecular Breeding 3:381-390.

Kistler, H. C. and Miao, V. P. W. 1992. New modes of genetic change in filamentous fungi. Annu. Rev. Phytopathol. 30:131152.

Kumar, N., Jhang, T., Vir, S. and Sharma, T. R. 2010. Molecular and pathological characterization of Colletotrichum falcatum infecting subtropical Indian sugarcane. J. Phytopathol. 159:260-267.

Levi, A., Rowland, L. J. and Hartung, J. S. 1993. Production of reliable randomly amplified polymorphic DNA (RAPD) markers from DNA of woody plants. Hort. Sci. 28:11881190.

Luikart, G., Allendorf, J. M., Cornuet, J. M. and Sherwin, W. B. 1998. Distortion of allele frequency distributions provides a test for recent population bottlenecks. J. Hered. 89:238-247.

Masel, A. M., He, C., Poplawski, A. M., Irwin, J. A. G. and Manners, J. M. 1996. Molecular evidence for chromosome transfer between biotypes of Colletotrichum gloeosporioides. Mol. Plant Microbe Interact. 5:339-348.

McDonald, B. A. 1997. The population genetics of fungi: Tools and Techniques. Physiopathology 87:448-453.

McDonald, B. A. and Linda, C. 2002. Pathogen population genetics, evolutionary potential, and durable resistance. Аппи. Rev. Phytopathol. 40:349-379.

Milgroom, M. G. 1996. Recombination and the multilocus structure of fungal populations. Annu. Rev. Phytopathol. 34:457-477.

Mort, M. E., Crawford, D. J., Santos-Guerra, A., Francisco-Ortega, J., Esselman, E. J. and Wolfe, A. D. 2003. Relationships among the Macaronesian members of Tolpis (Asteraceae: Lactuceae) based upon analyses of inter-simple sequence repeat (ISSR) markers. Taxon 52:511-518.

Mordue, J. E. M. 1971. Glomerella cingulata. CMI Description of Pathogenic Fungi and Bacteria, No. 315. Commonwealth Mycol. Inst., Kew, UK.

Mullis, K., Faloona, F. A., Scharf, S., Saiki, R., Horn, G. and Erlich, H. 1986. Specific enzymatic amplification of DNA in vitro: The polymerase chain reaction. Cold Spring Harbor Symposium on Quantitative Biology LI:263-273.

Nybom, H. 2004. Comparison of different nuclear DNA markers for estimating intraspecific genetic diversity in plants. Mol. Ecol. 13:1143-1155.

Penner, G. A., Bush, A., Wise, R., Kim, W., Domier, L., Kasha, K., Laroch, A., Scoles, G. S. and Gedak, G. 1993. Reproducibility of random amplified polymorphic DNA (RAPD) analysis among laboratories. PCR Meth. Appl. 2:341-345.

Qian, W., Ge, S. and Hong, D. Y. 2001. Genetic variation within and among populations of a wild rice Oryza granulate from China detected by RAPD and ISSR. Theor. Appl. Genet. 102:440-449.

Ratanacherdchai, K., Wang, H. K., Lin, F. C. and Soytong, K. 2007. RAPD analysis of Colletotrichum species causing chilli anthracnose disease in Thailand. J. Agr. Technol. 3:211-219.

Ratanacherdchai, K., Wang, H. K., Lin, F. C. and Soytong, K. 2010. ISSR for comparison of cross-inoculation potential of Colletotrichum capsici causing chilli anthracnose. Afri. J. Microbiol. Res. 4:76-83.

Rohlf, E. J. 1993. NTSYS-pc: numerical taxonomy and multivariate analysis system, version 1.80. Applied Biostatistics Inc., Setauket, New York.

Sachse, K. 2004. Specificity and performance of PCR detection assays for microbial pathogens. Mol. Biotechnol. 26:61-79.

Sambrook, J., Fritsch, E. and Maniatis, T. 1989. Molecular Cloning: A Laboratory Manual. 2nd edn. New York: Cold Spring Harbor Press.

Serraj, R. 2004. Symbiotic nitrogen fixation: challenges and future prospects for application in tropical agrosystems. Oxford and IBH, New Delhi, India.

Sherriff, C., Whelan, M. J., Arnold, G. M., Lafay, J. F., Brygoo, Y. and Bailey, J. A. 1994. Ribosomal DNA sequence analysis reveals new species groupings in the genus Colletotrichum. Exp. Mycol. 18:121-138.

Sherriff, C., Whelan, M. J., Arnold, G. M. and Baily, J. A. 1995. rDNA sequence analysis confirms the distinction between Colletotrichum graminicola and C. sublineolum. Mycolog. Res. 99:475-478.

Sutton, B. C. 1980. The Coelomycetes; fungi imperfecti with pycnidia, acervuli and stromata. Commonwealth Mycological Institute, Kew, London. 523-527.

Sutton, B. C. 1992. The Genus Glomerella and its anamorph Colletotrichum, In: Bailey, J. A. and Jeger, M. J. (eds) Colletotrichum: Biology, Pathology, and Control. CAB International, Wallingford, PP. 1-26.

Talbot, N. J. 2001. Nucleic acid isolation and analysis, In: Talbot, N. J. (ed) Molecular and Cellular Biology of Filamentous 
Fungi, Oxford: Oxford University Press, PP. 23-26.

Tamura, K., Peterson, D., Peterson, N., Steker, G., Nei, M. and Kumar, S. 2011. MEGA5; Molecular evolutionary genetics analysis using maximum likelihood, evolutionary distance, and maximum parsimony methods. Mol. Biol. Evol. 28:27312739.

Taylor, J. W., Jacobson, D. J., Kroken, S., Kasuga, T., Geiser, D. M., Hibbett, D. S. and Fisher, M. C. 2000. Phylogenetic species recognition and species concepts in fungi. Fungal Genet. Biol. 31:21-32.

Than, P. P., Jeewon, R., Hyde, K. D., Pongsupasamit, S., Mongkolporn, O., Taylor, P. W. J. (2008). Characterization and pathogenicity of Colletotrichum species associated with anthracnose on chilli (Capsicum spp.) in Thailand. Plant Pathol. 57:562-572.

Thompson, J. D., Higgins, D. G., Gibson, T. J. 1994. Clustal W; Improving the sensitivity of progressive multiple sequence alignment through sequence weighting, position specific gap penalties and weight matrix choice. Nucleic Acids Res.
22:4673-4680.

Williams, J. G. K., kubelik, A. R., Livvak, K. J., Rafalski, J. A. and Tingey, S. V. 1990. DNA polymorphisms amplified by arbitrary primers are useful as genetic markers. Nucleic Acids Res. 18:6531-6535.

White, T. J., Bruns, T., Lee, S. and Taylor, J. 1990. Amplification and direct sequencing of fungal ribosomal RNA genes for phylogenetics, In: Innis, M. A., Gelfand, D. H., Sninsky, J. J. and White, T. J. (eds) PCR Protocols: a guide to methods and applications, Academic Press, New York, USA, PP. 315-322.

Wolfe, A. D. and Liston, A. 1998. Contributions of PCR-based methods to plant systematics and evolutionary biology. In: Plant Molecular Systematics II eds. Soltis, D. E., Soltis, P. S. and Doyle, J. J. pp. 43-86. Kluwer.

Zietkiewicz, E., Rafalski, A. and Labuda, D. 1994. Genome fingerprinting by simple sequence repeat (SSR) - anchored polymerase chain reaction amplification. Genomics 20:176183. 